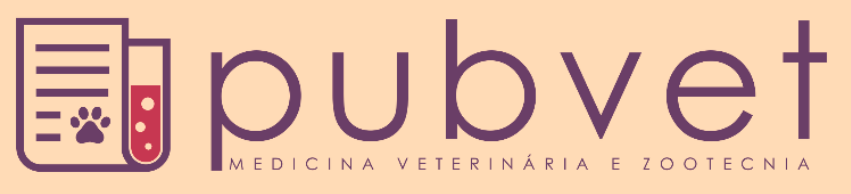

https://doi.org/10.31533/pubvet.v14n9a656.1-6

\title{
Gastrointestinal parasites of pig raised on a pig farm in Nova Iguaçu, Rio de Janeiro
}

\author{
Érica Sant'Anna Melo ${ }^{1}$, Ana Claudia de Menezes Cruz $^{2}{ }^{\bullet}$, Camila Souza Carvalho Class ${ }^{30}$, \\ Alynne da Silva Barbosa ${ }^{4}$, Silvio Jorge Machado ${ }^{5}$, Gil Vicente Oliveira da Silva ${ }^{6}{ }^{\circ}$, Fabiana \\ Batalha Knackfuss $^{6}{ }^{\circ}$, Renato Luiz Silveira ${ }^{7} 0^{\circ}$ \\ ${ }^{\prime}$ Veterinarian, Nova Iguaçu-RJ. \\ ${ }^{2}$ Veterinarian, PhD, NAL, Universidade Federal Fluminense - UFF, Niterói, Rio de Janeiro, Brasil. \\ ${ }^{3}$ Biologist, Mastering Student. Departamento de Microbiologia e Parasitologia, Instituto Biomédico, UFF, Niterói, Rio de Janeiro, Brasil. \\ ${ }^{4}$ Veterinarian, PhD, Professor. Departamento de Microbiologia e Parasitologia, Instituto Biomédico, UFF, Niterói, Rio de Janeiro, Brasil. \\ ${ }^{5}$ Biomedic, Multidisciplinary Laboratorie, Universidade do Grande Rio - UNIGRANRIO, Duque de Caxias, Rio de Janeiro. \\ ${ }^{6}$ Veterinarian, PhD, Professor. Escola de Ciências da Saúde - Universidade do Grande Rio, Duque de Caxias, Rio de Janeiro. \\ ${ }^{7}$ Veterinarian, PhD, Professor. Departamento de Morfologia, Instituto Biomédico, UFF, Niterói, Rio de Janeiro, Brasil. \\ *Autor correspondente, E-mail: renatosilveira@id.uff.br
}

\begin{abstract}
At the national level, there are several types of pig breeding that employ diversified technologies and management, depending on the financial conditions of each producer. This difference, evidenced in the productions, ends up reflecting the presence of infectious agents in animals, including infections determined by gastrointestinal parasites such as helminths and protozoa. Due to the lack of information and the importance of this topic, this study aimed to report, through a parasitological survey, the frequency of gastrointestinal parasites detected in pig raised on a farm located in the Nova Iguaçú city, Rio de Janeiro. For this purpose, 200 fecal samples from 40 pens were collected. Fecal samples were processed in a pool using the Lutz spontaneous sedimentation technique. In $100 \%$ of the samples, forms of parasites were detected, being mainly strongyles eggs (97.5\%), followed by coccidia oocysts $(87.5 \%)$, Balantioides coli cysts (75\%), Strongyloides ransomi eggs (42.5\%), Ascaris suum (25\%) eggs and Trichuris suis (7.5\%), with statistically significant differences between these frequencies. From the parasitological survey carried out, it was possible to identify a high frequency of parasites in the fecal samples of the animals, confirming that the pig farm had precarious conditions for sanitary management.
\end{abstract}

Keywords: helminths, parasites, pig farming, protozoa

\section{Parasitos gastrointestinais de suínos criados em uma granja em Nova Iguaçu, Rio de Janeiro}

Resumo. Em âmbito nacional existem vários tipos de criação de suínos que empregam tecnologias e manejos diversificados, dependendo das condições financeiras de cada produtor. Esta diferença, evidenciada nas produções, acaba refletindo na presença de agentes infecciosos nos animais, incluindo as infecções determinadas por parasitos gastrointestinais como os helmintos e protozoários. Mediante a falta de informações e a importância sobre a temática, este estudo teve como objetivo relatar por meio de um inquérito parasitológico, a frequência de parasitos gastrointestinais detectados em fezes de suínos mantidos em uma granja localizada no município de Nova Iguaçú-RJ. Para tal, foram coletadas 200 amostras fecais de 40 baias. As amostras fecais foram processadas em pool pela técnica de sedimentação espontânea de Lutz. Em $100 \%$ das amostras foram detectadas formas evolutivas de parasitos, sendo principalmente ovos de estrongilídeos 
(97,5\%), seguido de oocistos de coccídios (87,5\%), cistos de Balantioides coli (75\%) ovos larvados de Strongyloides ransomi (42,5\%), ovos de Ascaris suum (25\%) e Trichuris suis (7,5\%), tendo sido observadas diferenças estatísticas significativas entre essas frequências. A partir do inquérito coproparasitológico realizado, foi possível identificar elevada frequência de parasitos nas amostras fecais dos animais, confirmando que a propriedade apresentava precárias condições de manejo sanitário.

Palavras chave: criação de suínos, helmintos, parasitos, protozoários

\section{Parásitos gastrointestinales de cerdos criados en una granja en Nova Iguaçu, Río de Janeiro}

Resumen. A nivel nacional, existen varios tipos de cría de cerdos que emplean tecnologías y manejo diversificados, dependiendo de las condiciones financieras de cada productor. Esta diferencia, evidenciada en las producciones, termina reflejando la presencia de agentes infecciosos en animales, incluyendo infecciones determinadas por parásitos gastrointestinales como helmintos y protozoos. Debido a la falta de información y la importancia del tema, este estudio tuvo como objetivo informar, a través de una pesquisa parasitológica, la frecuencia de los parásitos gastrointestinales detectados en las heces de cerdo mantenidas en una granja ubicada en el municipio de Nova Iguaçú-RJ. Para este propósito, se recolectaron 200 muestras fecales de 40 puestos. Las muestras fecales se procesaron en pool utilizando la técnica de sedimentación espontánea de Lutz. En el 100\% de las muestras, se detectaron formas evolutivas de parásitos, principalmente huevos de strongyles eggs ( $97.5 \%$ ), seguidos de oocistos de coccidio (87.5\%), quistes de Balantioides coli (75\%) huevos de larvas de Strongyloides ransomi (42.5\%), huevos de Ascaris suum $(25 \%)$ y Trichuris suis (7.5\%), con diferencias estadísticas significativas entre estas frecuencias. A partir de la pesquisa coproparasitológica realizada, fue posible identificar una alta frecuencia de parásitos en las muestras fecales de los animales, confirmando que la propiedad presentaba condiciones precarias para el manejo sanitario.

Palabras clave: cría de cerdos, helmintos, parásitos, protozoos

\section{Introduction}

Brazil is the fourth largest pork producer and exporter in the world (Embrapa, 2018). The pig activity is very important for the country's economic and social development (Carreiro et al., 2016). At the national sphere, there are several types of pig breeding that employ diversified technologies and handling, depending on the financial conditions of each producer (Barbosa et al., 2015).

This great diversity evidenced in the productions, ends up reflecting the presence of infectious agents in animals, including infections by gastrointestinal parasites, such as helminths and protozoa. These infections do not always cause visible changes in animals, but they can directly affect their development, causing weight loss, decrease in growth, increased mortality, in addition to expenses arising from the purchase of medicines (Brito et al., 2012).

Despite the great development of intensive pig farming, little is known about the frequency of parasites in the properties, especially in those that do not follow the sanitary protocols of industrial farms. In intensive production systems, the presence of gastrointestinal parasites is directly related to the adopted sanitary management, being, therefore, excellent bioindicators of the health of the pig breeding (Barbosa et al., 2015).

In the state of Rio de Janeiro, there are only two studies on gastrointestinal parasites in pigs. One carried out on industrial farms located in Petrópolis and Itaperuna cities and on family farms located in the metropolitan and coastal lowlands cities (Barbosa et al., 2015), and the other carried out on semiintensive system in Pinheral city (Carreiro et al., 2016). Due to the lack of information, this study aimed to report, through a parasitological survey, the frequency of gastrointestinal parasites detected in pig feces bred on a property located in Nova Iguaçú, Rio de Janeiro. 


\section{Material and methods}

This study was approved by the Animal Use Ethics Committee from Universidade Federal Fluminense, CEUA/UFF 7148220519, and carried out on a property located in Nova Iguaçu, Rio de Janeiro.

The animals were kept in masonry pens, built without organization and standardization. These pens had, in general, poorly maintained cement floors. Some pens were completely covered with a roof of the fiber cement type, while in others the coverage was partial. At the farm, animal density was not respected and the pigs were not separated by categories or by age groups in the pens.

The water used for cleaning and feeding was obtained from an artesian well and by a public company. The feeding of the animals consisted of food remnants from restaurants and supermarkets, being administered twice a day. The animals received anthelmintics based on fenbendazole in the feeding sporadically and were not vaccinated. The only supplementation took place on the second day of life, when piglets, received an iron injection intramuscularly.

Aiming at animal welfare, and avoiding the stress of containment, fresh feces were collected directly from the floor from the 40 pens on the farm in the morning, with five fecal samples taken from each, totaling 200 samples.

Only fresh feces were collected, those that were not trampled or mixed with urine, and even then, only their upper parts, avoiding to collect the part of the sample in direct contact with the floor. They were collected in new plastic bags, which were identified with the number of each pen and stored in thermal boxes. Soon after collection, the samples were immediately sent to the Multidisciplinary Laboratory of the Universidade do Grande Rio-UNIGRANRIO and Parasitology Laboratory of the Biomedical Institute of Universidade Federal Fluminense-UFF.

In the laboratory, fecal samples were processed in a pool, that is, the five samples from each stall were added, totaling 40 samples. For this, they were gathered in a single plastic bag, being sealed with a knot. Afterward, the feces were mixed and homogenized gently. The sample was subjected to parasite research using the spontaneous sedimentation technique by Lutz (1919). The slides containing the fecal sediment were covered with coverslips $24 \times 32 \mathrm{~mm}$ and read in an Olympus BX 41 optical microscope in 100x magnification, with the parasite being confirmed in 400x. In the end, the parasites were identified by means of a descriptive analysis taking into account the total number of pens, with the general frequency of the infecting agents being presented, as well as each taxonomic group of parasites identified.

In order to analyze the existence of significant statistical differences between the frequencies of the parasites found in the samples, the Chi-square test was used, being considered a $1 \%$ probability. For this, the program SPSS 25.0 was used.

\section{Results}

The 40 fecal samples analyzed were positive for gastrointestinal parasites, with nematodes and protozoa being detected. Significant statistical differences were observed by the Chi-square test $\left(\chi^{2}=\right.$ $47.07, \mathrm{p}<0.01)$ between the parasites found, with higher frequencies of detected strongyles eggs in 39 samples (97.5\%), followed by non-sporulated coccidia oocysts in 35 (87.5\%), Balantioides coli cysts in $30(75 \%)$, thin-shell eggs similar to Strongyloides ransomi in 17 (42.5\%), Ascaris suum eggs in 10 (25\%) and Trichuris suis in 3 (7.5\%) (Figure 1).

\section{Discussion}

All pool fecal samples analyzed were positive for gastrointestinal parasites. Results inferior to those evidenced in this study, were reported in family farms located in the Federal District (96.14\%), Sergipe (90\%) and in other cities in Rio de Janeiro (93.1\%) (Aguiar, 2009; Barbosa et al., 2015; Brito et al., 2012). Also, lower frequencies were reported in farms with industrial production system located in Minas Gerais (38.6\% - 62.9\%), in São Paulo (39.7\%), Espírito Santo (31\%) and Pernambuco (1.6\%). In a semi-confinement breeding system in the state of Rio de Janeiro, the frequencies found were $72.7 \%$ in Pinheral, 68.5\% in Petrópolis and 39\% in Itaperuna (Antunes et al., 2011; Barbosa et al., 2015; 
Carreiro et al., 2016; D’Alencar et al., 2006; Hoff et al., 2005; Nishi et al., 2000). The high frequency of parasites detected in the feces collected in the pig pens in Nova Iguaçu was already expected, due to the bad physical and sanitary conditions observed. Despite the fact that anthelmintics are provided to pigs, albeit in an irregular manner, the high frequency of parasitism seems to be linked, mainly, to the lack of hygiene in the raising of animals, highlighting the large amount of organic matter, feces and urine, seen in animal pens.

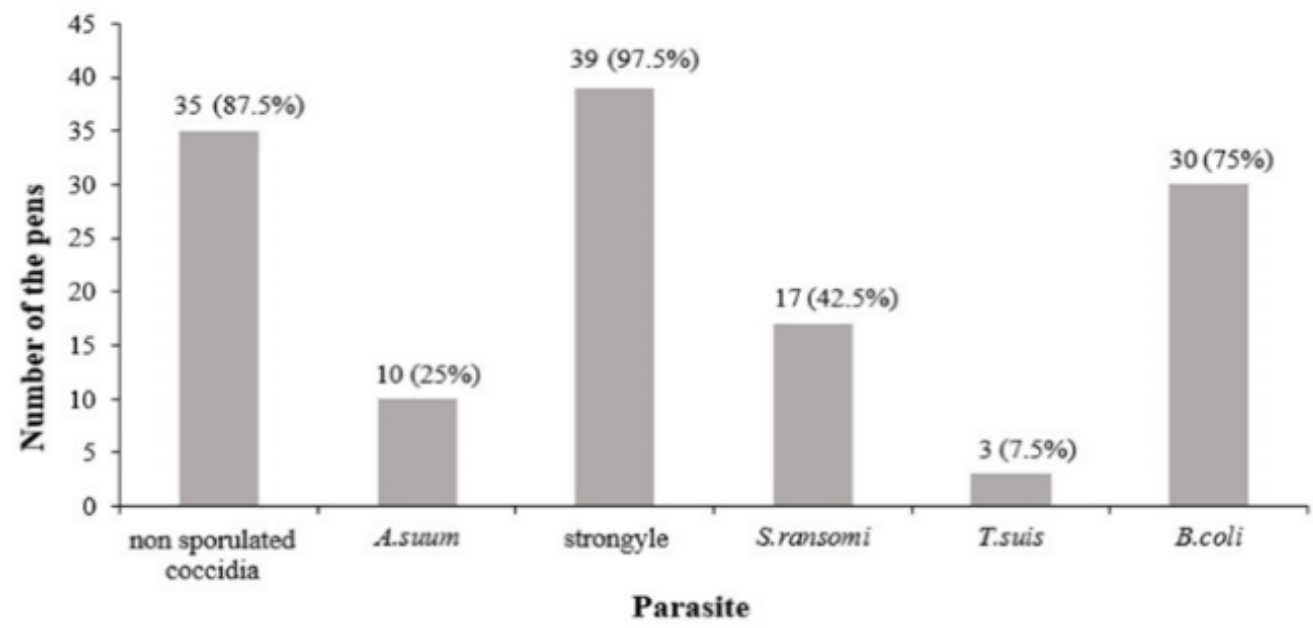

Figure 1. Frequency of gastrointestinal parasites detected in pig raised on a pig farm located in Nova Iguaçu, Rio de Janeiro.

At the farm, the sanitary break was not carried out at any stage of breeding, and the housing density was not respected in most of pens. According to Rhor (2014), by not respecting animal density, animal health and zootechnical performance are directly affected. Associated with this, the use of water layer on the floor, greatly favored parasitic transmission by allowing the parasites to remain in the environment through reinfection (Barbosa et al., 2015).

Even though the farms keeps the resources confined, it will not present general care and mainly sanitary, which are generally observed in the industrial farms. It is worth mentioning that the property had a large number of animals for sale. This situation, in most cases, is not observed in family farms, which generally raise pigs as a source of subsistence. In this way, as resources observed in the property of the study made it difficult to classify its production system, which was not of the family type, but was also far below the technological system. This difficulty in classifying pig production systems in Brazil has also been observed in pig farms in Paraiba, Pernambuco and Rio Grande do Norte ( al., 2011; Silva Filha et al., 2008).

It is important to note that this study did not aim to analyze the prevalence of pig parasites but to verify, through parasitological examination, the health of the production that visually did not seem to be adequate. Thus, it was claimed to collect fecal samples directly from the floor of each pen and process them in a pool. This form of collection and analysis has also been carried out in farms industrial in France by Belœil et al. (2003). These authors pointed that the collection of the floor and the processing of the samples in this system ends up being less tiring for the researchers and faster, besides favoring the animal welfare, avoiding the stress of capturing the pig and the rectal palpation.

Among the parasites, the most frequently detected were strongyles eggs. In this group, both eggs of the Superfamily Strongyloidea and those of the Superfamily Trichostrongyloidea were considered, since they are similar, requiring cultures or molecular analyzes to differentiate them properly (Brewer \& Greve, 2019). It is important to note that strongyles, mainly Hyostrongylus rubidus and Oesophagostomum sp., can determine economic losses in production, since the sows infected with these parasites develop the "poor sow syndrome" that occurs during the suckling period of the piglets (Roepstorff \& Nansen, 1998).

In addition to these nematodes, Strongyoides ransomi eggs were also detected, as well as Ascaris suum and Trichuris suis. These helminths are highly important in pig farming, as they cause a reduction in the weight gain of pigs, that is, a worsening in feed conversion, which in the case of A. suum and $T$. 
suis occurs precisely in the fattening phase (Brewer \& Greve, 2019; Roepstorff \& Nansen, 1998). In addition, infection by A. suum also causes condemnation of the pig's liver in the slaughterhouse due to the appearance of milk spots, points of fibrosis that are formed due to the larval migration of the nematode. Strongyloides ransomi, on the other hand, is a parasite that mainly affects younger piglets, triggering severe catarrhal enteritis. It is noteworthy that the sow act as the main source of infection for the piglets, since the parasite can be transmitted via percutaneous, oral, and transmammary (Linhares et al., 2012; Nansen \& Roepstorff, 1999). The poor sanitary management observed on the property clearly seems to have favored the high parasitism by the nematodes highlighted above.

The lack of supply of anthelmintics on a routine basis, the accumulation of excreta observed in the animals' pens, due to the lack of periodic cleaning of them, associated with the humid tropical climate of the state of Rio de Janeiro, ended up allowing the rapid formation of structures infective parasites, third stage larvae and larvae eggs, culminating in infections and, consequently, with the high frequency of parasitic diseases evidenced in the study.

The second group of parasites most detected was coccidia, corresponding to non-sporulated oocysts compatible with the genus Eimeria sp. and Cystoisospora suis. The latter species is more important in pig coccidiosis, due to its high pathogenic potential for these animals, mainly for piglets, between 5 and 15 days of age, determining gastrointestinal infections with acute diarrheal crises (Linhares et al., 2012). In addition to poor sanitary management, favor the maintenance of coccidia oocysts in the environment, the agglomeration of animals, and the lack of separation of these by categories and age groups, also may favor the transmission of coccidia and other parasites among asymptomatic animals and the most sensitive age groups, such as piglets, increasing the number of deaths in the herd (Takeuti et al., 2019). Lindsay et al. (2019), called attention to the fact that concomitant bacterial and viral infections can worsen the condition and still make diagnosis difficult.

Also with a high frequency, cystic forms of the protozoan Balantioides coli were detected in the fecal samples of the pigs. Despite the pig being considered an asymptomatic host, scientific studies are still lacking to verify if the infection by this parasite interferes in the zootechnical indexes of that animal. Even so, B. coli is a zoonotic parasite, pig being the main reservoir of this parasite, which can be transmitted to humans and determine in these severe dysenteric conditions (Barbosa et al., 2018). It is worth mentioning that the studied property was located in a residential neighborhood on the outskirts of the city. Even though the local population does not have direct contact with pig, B. coli cysts can be carried with the leaching of rain, contaminating the neighborhood's soil, as well as the water reservoirs, thus favoring the transmission of this protozoan to the local population. This fact corroborates with Schuster \& Ramirez-Avila (2008), who affirm that human infection is more prevalent in areas close to pigs. From the parasitological survey carried out, it was possible to identify a high frequency of parasites in the fecal samples of the animals, confirming that the property had precarious conditions for sanitary management.

\section{Referências bibliográficas}

Aguiar, P. C. (2009). Aspectos epidemiológicos das parasitoses gastrintestinais de suínos naturalizados de criações familiares do Distrito Federal [Universidade Federal de Brasília]. Dissertação

Antunes, R. C., Carrazza, L. G., Sant'ana, D. S., Oliveira, M. T., \& Carrazza, T. G. (2011). Prevalência de parasitos gastrintestinais em leitões de terminação relacionada com densidade de alojamento e sexo. PUBVET, 5, Art-1019.

Barbosa, A.S., Dib, L. V., \& Uchôa, C. M. A. (2018). Balantidium coli. In Liu D (Ed.), Handbook of Foodborne Diseases. (pp. 531-540). Florida: CRC Press.

Barbosa, Alynne S., Bastos, O. M. P., Dib, L. V., Siqueira, M. P., Cardozo, M. L., Ferreira, L. C., Chaves, W. T., Fonseca, A. B. M., Uchôa, C. M. A., \& Amendoeira, M. R. R. (2015). Gastrointestinal parasites of swine raised in different management systems in the State of Rio de Janeiro, Brazil. Pesquisa Veterinária Brasileira, 35(12), 941-946. https://doi.org/10.1590/S0100-736X2015001200001

Belœil, P. A., Chauvin, C., Fablet, C., Jolly, J. P., Eveno, E., Madec, F., \& Reperant, J. M. (2003). Helminth control practices and infections in growing pigs in France. Livestock Production Science, 81(1), 99-104. https://doi.org/10.1016/S0301-6226(02)00192-6 
Brewer, M. T., \& Greve, J. H. (2019). Internal Parasites. In: Diseases of Swine (pp. 1028-1040). Wiley. https://doi.org/10.1002/9781119350927.ch67

Brito, G. G., Santos, T. B., Melo, C. M., \& Jeraldo, V. L. S. (2012). Ocorrência de enteroparasitas em amostras fecais de suínos do município de Simão Dias-SE. Caderno de Graduação-Ciências Biológicas e Da Saúde-UNIT-SERGIPE, 1(1), 11-18.

Carreiro, C. C., Coelho, C. D., Jorge, J. L. B. P., Costa, N. O. G., Paiva, R. V., Teixeira Filho, W. L., Rosa, A. G., \& Jesus, V. L. T. (2016). Parasitos intestinais em suínos confinados em uma criação no município de Pinheiral, RJ. Brazilian Journal of Veterinary Medicine, 38(Supl. 2), 117-122. http://rbmv.org/index.php/BJVM/article/view/199

D’Alencar, A. S., Faustino, M. A. G., Sousa, D. P., Lima, M. M., Alves, L. C., \& Ribeiro, T. C. F. S. (2006). Infecção por helmintos e coccídios em criação de suínos de sistema confinado localizada no município de Camaragibe-Pe. Ciência Veterinária Nos Trópicos, 9(2/3), 79-86.

Embrapa. (2018). Qualidade da carne suína. Online. https://www.embrapa.br/qualidade-da-carne/carnesuina

Hoff, G., Silva, A. S., \& Monteiro, S. G. (2005). Avaliação do parasitismo e comparação de técnicas de análise fecal em suínos de granjas da região oeste do estado de Santa Catarina. Revista Da FZVA, 12(1), 106-115.

Lindsay, D. S., Dubey, J. P., \& Santín-Durán, M. (2019). Coccidia and Other Protozoa. In: Diseases of Swine (pp. 1015-1027). Wiley. https://doi.org/10.1002/9781119350927.ch66

Linhares, G. F. C., Sobestiansky, J., Linhares, D., Barcellos, D., Moreno, A. M., \& Matos, M. P. C. (2012). Endoparasitoses. Doenças Dos Suínos. $2^{a}$ Ed. Cânone Editorial, Goiânia, 433-466.

Lutz, A. O. (1919). Schistosomum mansoni e a schistosomatose segundo observações feitas no Brasil. Memórias Do Instituto Oswaldo Cruz, 11(1), 121-155.

Nansen, P., \& Roepstorff, A. (1999). Parasitic helminths of the pig: factors influencing transmission and infection levels. International Journal for Parasitology, 29(6), 877-891. https://doi.org/10.1016/S0020-7519(99)00048-X

Nishi, S. M., Gennari, S. M., Lisboa, M., Silvestrim, A., Caproni Jr, L., \& Umehara, O. (2000). Parasitas intestinais em suínos confinados nos estados de São Paulo e Minas Gerais. Arquivos Do Instituto Biológico, 67(2), 199-203.

Rhor, S. A. (2014). Programa de limpeza e desinfecção de instalações em suinocultura. In: ABCS. Produção de Suínos: Teoria e Prática. Brasília-DF, Gráfica Qualitá, 615-622.

Roepstorff, A., \& Nansen, P. (1998). Epidemiology, diagnosis and control of helminth parasites of swine (Vol. 3). Rome: FAO Animal Health Manual.

Schuster, F. L., \& Ramirez-Avila, L. (2008). Current World Status of Balantidium coli. Clinical Microbiology Reviews, 21(4), 626-638. https://doi.org/10.1128/CMR.00021-08

Silva Filha, O L, Barbosa, E. J. R., Lima, A. D., Melo, A. G. P., Melo Filho, A. J., \& Sá, M. S. (2011). Os produtores de suínos no município de Floresta, estado de Pernambuco, Brasil. Actas Iberoamericanas de Conservación Animal, 1, 416-418.

Silva Filha, Olimpia Lima, Pimenta Filho, E. C., Souza, J. F., Oliveira, Â. de S., Oliveira, R. J. F., Melo, M., Melo, L. M., Araújo, K. Â. O., \& Sereno, J. R. B. (2008). Caracterização do sistema de produção de suínos locais na microrregião do Curimataú Paraibano. Revista Brasileira de Saúde e Produção Animal, 9(1).

Takeuti, K. L., Conti, E. R., Mazzarollo, A., \& Barcellos, D. E. (2019). Fatores predisponentes para a ocorrência de diarreias na maternidade. In Bortolozzo, F.P., Wentz I., Takeuti K.L., Mellagi A.P.G., Ulguim R..R., Barcellos D.E. (Ed.), Avanços em sanidade, produção e reprodução de suínos (pp. 89-104). IV. XII SINSUI. Porto Alegre, Gráfica da UFRGS.

Recebido: 18 de julho, 2020.

Aprovado: 14 de agosto, 2020 .

Disponível online: 11 de setembro, 2020

Licenciamento: Este artigo é publicado na modalidade Acesso Aberto sob a licença Creative Commons Atribuição 4.0 (CC-BY 4.0), a qual permite uso irrestrito, distribuição, reprodução em qualquer meio, desde que o autor e a fonte sejam devidamente creditados. 